\title{
Temporary prosthetic restorations in digital technology - literature review
}

\author{
Uzupełnienia tymczasowe w technologii cyfrowej \\ - przegląd piśmiennictwa
}

\section{Paula Aleksandra Lasica, Teresa Sierpińska, Dorota Cylwik-Rokicka}

Zakład Protetyki Stomatologicznej, Specjalistyczna Lecznica Stomatologiczna Uniwersytetu Medycznego w Białymstoku

Department of Prosthodontics, Medical University of Bialystok

Kierownik: prof. dr hab. n. med. Teresa Sierpińska

KEY WORDS:

PMMA, CAD/CAM, 3D printers, temporary restorations, temporary materials

\section{Summary}

Temporary restorations are the main standard in dental prosthetic treatment. In the era of widespread access to digital technology, it has become natural to use it for the purpose of aesthetic, functional and precise restorative solution between visits, as well as part of comprehensive multi-specialist rehabilitation. There are many technologies and materials available on the market, and yet manufacturers are still trying to quality improvement of their products.

The aim of the literature review was to systematize the current knowledge of the available materials, the scope of possibilities and techniques of making temporary restorations in digital technology. PubMed and Google Scholar literature databases have been reviewed.

The analysis of the literature indicated that in dental prosthetics two basic digital technologies can be distinguished: subtractive method (milling-CAD/CAM) and the additive method ( $3 D$ printing). The most important features of both methods are presented here, highlighting the key differences.
HASŁA INDEKSOWE:

PMMA, CAD/CAM, drukarki 3D, uzupełnienia tymczasowemateriały tymczasowe

\section{Streszczenie}

Uzupetnienia tymczasowe sa standardem $w$ leczeniu protetycznym. $W$ dobie powszechnego dostępu do technologii cyfrowych, naturalna stata sie potrzeba wykorzystania ich celem estetycznego, funkcjonalnego i precyzyjnego zaopatrzenia pacjenta pomiędzy wizytami, a także $w$ ramach kompleksowej rehabilitacji wielospecjalistycznej. Na rynku dostepnych jest wiele technologii i materiałów, a producenci wciąz dąża do poprawy jakości swoich produktów.

Celem opracowania byto usystematyzowanie wiedzy na temat dostęnych materiatów, zakresu możliwości i techniki wykonywania uzupetnień tymczasowych w technologii cyfrowej. Dokonano przegladu piśmiennictwa wykorzystujac baze danych PubMed oraz Google Scholar.

Analiza piśmiennictwa wykazała, że w protetyce stomatologicznej wyróżnia się dwie podstawowe technologie cyfrowe: wykorzystujace metode ubytkowa - subtrakcyjna (frezowanie - CAD/ CAM) oraz metodę addytywna (druk 3D). Przedstawiono najważniejsze cechy obu metod oraz wyodrębniono zauważone różnice. 
Permanent temporary restorations, for the protection of teeth after preparation, are standard in modern prosthetic treatment. ${ }^{1}$ These restorations may constitute short-term or longterm protection as part of a multi-specialist treatment and rehabilitation plan. The use of temporary crowns or bridges between visits is one of the basic elements of prophylaxis in dental prosthetics. The basic roles of permanent temporary restorations are:

- protection of the pulp of the prepared tooth against the harmful effects of external factors - chemical, physical and mechanical,

- periodontal protection,

- maintaining the parallelism of the abutments,

- maintaining the correct occlusal height and preventing teeth extrusion,

- preservation of the support zones,

- maintaining the proper chewing function,

- ensuring correct articulation,

- meeting the aesthetic requirements that guarantee the psychological comfort of the patient,

- assessment and diagnosis of future treatment effects, especially in the case of complex, multi-specialist treatment. ${ }^{2-5}$

In order to fulfil these functions, the correct clinical and laboratory stages, as well as the use of appropriate materials, are essential. This condition applies to both polished natural teeth and abutment implants. The self-cured composite material is used most commonly for direct temporary restorations. Indirect restorations (made in the lab) utilize composite and acrylic resin. However, in the era of widespread access to digital technology, it has become natural to use them for aesthetic and accurate temporary restorations. The use of digital technology began in the United States Air Force with the production of military protective equipment in 1950, and then in the 1970s, when Bruce Altschuler (USA), Francois Duret (France),
Stałe uzupełnienia tymczasowe, jako zabezpieczenie zębów po oszlifowaniu, stanowią standard we współczesnym leczeniu protetycznym. ${ }^{1}$ Uzupełnienia te mogą stanowić zabezpieczenie krótkoczasowe lub długoczasowe, jako element wielospecjalistycznego planu leczniczo-rehabilitacyjnego. Stosowanie koron czy mostów tymczasowych pomiędzy wizytami pacjenta jest jednym z podstawowych elementów profilaktyki w protetyce stomatologicznej. Do podstawowych zadań stałych uzupełnień tymczasowych należą:

- ochrona miazgi oszlifowanego zęba przed szkodliwym działaniem czynników zewnętrznych - chemicznych, fizycznych i mechanicznych,

- ochrona przyzębia,

- zachowanie równoległości filarów,

- zachowanie prawidłowej wysokości zwarciowej oraz zapobieganie wysuwaniu zębów,

- zachowanie stref podparcia,

- zachowanie prawidłowej funkcji żucia,

- zapewnienie prawidłowej wymowy,

- zaspokojenie wymagań estetycznych, gwarantujących psychiczny komfort pacjenta,

- ocena i diagnozowanie przyszłych efektów leczenia, zwłaszcza w przypadku skomplikowanego, wielospecjalistycznego leczenia. ${ }^{2-5}$

Aby uzupełnienia tymczasowe mogły spełniać te funkcje niezbędna jest poprawność etapów klinicznych, laboratoryjnych oraz zastosowanie odpowiednich materiałów. Warunek ten dotyczy zarówno oszlifowanych zębów naturalnych jak i wszczepów filarowych.

Powszechnie do wykonania uzupełnień tymczasowych metodą bezpośrednią, stosowane są chemoutwardzalne materiały kompozytowe. Natomiast w metodzie pośredniej (w laboratorium techniki dentystycznej) wykonywane są z kompozytów i akrylu. Jednak w dobie rozwoju technologii cyfrowych, naturalną stała się 
Werner Mörmann and Marco Brandestini (Switzerland) conducted the first attempts to use the $\mathrm{CAD} / \mathrm{CAM}$ system in dentistry. ${ }^{6,7} \mathrm{CAD} /$ CAM (Computer Aided Design/Computer Aided Manufacturing) technology consists of three main components: the scanner, software and manufacturing devices. Scanners are used to transfer the conditions from the oral cavity to the dental laboratory. They are available as intraoral and laboratory devices. Currently, the clinic uses intraoral non-contact (optical) or tactile scanners. Non-contact scanners use white light or a laser beam that is reflected from the surface after registration and converted into digital data. Touch scanners, which are more expensive and require a complicated procedure, are used less frequently. 8,9 The technique of "digital impression" is an alternative to scanning a traditional impression or a model cast on its basis, which is performed with the help of laboratory scanners. ${ }^{10}$ Many studies show that patients prefer intraoral scanning, which is much faster compared to traditional impression methods. ${ }^{11,12}$ Additionally, it is an ideal solution in the case of trismus or gag reflex, and prevents damage to the traditional impression during transport or due to improper security protection. If re-imaging is necessary, it is possible to scan the selected fragment of the dental arch without repeating the entire impression procedure. ${ }^{14,15}$ It should also be emphasized that many studies indicate a better marginal fit of restorations made using digital technology based on optical impressions compared to traditional ones. ${ }^{16}$ The obtained digital data is saved in the universal STL format, in which the prosthetic work will be designed. The data can be processed using any software and transfer it to devices from various producers. As a result, the area of potential applications of "open systems" is much wider. ${ }^{17,18}$

The aim of the literature review is to systematize the available knowledge concerning the materials used, and the ranges potrzeba wykorzystania ich również do wykonawstwa uzupełnień tymczasowych.

Technologia cyfrowa miała swój początek w Amerykańskich Siłach Powietrznych, kiedy to $\mathrm{w} 1950 \mathrm{r}$. rozpoczęto produkcję środków ochrony militarnej a następnie w latach 70-tych, kiedy to Bruce Altschuler (USA), Francois Duret (Francja), Werner Mörmann i Marco Brandestini (Szwajcaria) przeprowadzili pierwsze próby wykorzystania systemu $\mathrm{CAD} / \mathrm{CAM}$ w stomatologii. ${ }^{6,7}$

Technologia CAD/CAM (Computer Aided Design/Computer Aided Manufacturing) składa się z trzech głównych elementów: skanera, oprogramowania i urządzenia produkującego. Skanery służą do przeniesienia warunków z jamy ustnej do pracowni techniki dentystycznej. Występują jako urządzenia wewnątrzustne i laboratoryjne. Obecnie w gabinecie wykorzystuje się skanery wewnątrzustne bezdotykowe (optyczne) lub dotykowe. Skanery bezdotykowe wykorzystują białe światło lub wiązkę lasera, które odbite od powierzchni po zarejestrowaniu są przetwarzane na dane cyfrowe. Skanery dotykowe, droższe, wymagające skomplikowanej procedury są rzadziej stosowane. ${ }^{8,9}$ Technika „cyfrowego wycisku” stanowi alternatywę dla skanowania tradycyjnego wycisku czy też odlanego na jego podstawie modelu, które wykonuje się przy pomocy skanerów laboratoryjnych. ${ }^{10}$ Wiele badań wskazuje, iż pacjenci preferują właśnie skanowanie wewnątrzustne, które jest znacznie szybsze w porównaniu z tradycyjnymi metodami 'wyciskowymi. ${ }^{11,12}$ Dodatkowo, stanowi dobre rozwiązanie w przypadku szczękościsku i odruchów wymiotnych oraz zapobiega uszkodzeniom tradycyjnego wycisku podczas transportu czy też nieprawidłowego zabezpieczenia, a w przypadku konieczności ponownego zobrazowania, możliwe jest doskanowanie wybranego fragmentu łuku zębowego, bez konieczności powtarzania całej procedury wyciskowej. ${ }^{13-15}$ Należy również zaznaczyć, 
of possibilities and techniques of making temporary restorations in digital technology.

PubMed database and Google Scholar were researched using the following key words: "CAD/CAM", "PMMA" and "3D printers". A total of 57 records meeting the assumed criteria were qualified for the analysis. After typing additional criteria namely "temporary restoration" and "temporary materials", 40 works were further selected, on modern digital technology.

Currently, in dentistry, there are two computer-aided manufacturing systems (CAM) of the designed prosthetic restoration: using the subtractive method (milling-CAD/CAM) or the additive method (3D printing).

\section{CAD/CAM technology}

CAM milling devices are the most frequently used digital systems in dental prosthetics due to many years of use. In this reduction technique, modern five-axis $\mathrm{CNC}$ milling machines produce a full range of prosthetic restorations from materials such as chromo-cobalt alloy, titanium, zirconium oxide and the latest generation polymers. ${ }^{9}$ The CAD/CAM technology allows individual temporary restorations to be made, such as single crowns, implant crowns, bridges, implant bridges, try-in, long-term temporary restorations in the case of adolescent patients, long-term temporary restorations in the case of occlusion reconstruction, and multi-specialist rehabilitation of the stomatognathic system. This meets the patients' aesthetic expectations (adjustment to the features and size of the face), and offers satisfactory functionality. It enables making temporary restorations directly in the dentist's office, using the CEREC Sirona device, and more often indirectly, with the use of a dental technology laboratory. ${ }^{16}$ Repeatability is an extremely important advantage: digital technology allows the design to be stored as a saved file, so that the next milling of the same restoration takes only a few minutes. Three że badania wskazują na lepsze dopasowanie brzeżne uzupełnień wykonanych w technologii cyfrowej na podstawie wycisków optycznych $\mathrm{w}$ porównaniu $\mathrm{z}$ tradycyjnymi. ${ }^{16}$

Uzyskane dane cyfrowe zapisywane są w uniwersalnym formacie STL, w którym zostanie zaprojektowana praca protetyczna. Daje on możliwość ich przetwarzania przy pomocy dowolnego oprogramowania oraz transferu do urządzeń pochodzących od różnych dostawców. Dzięki temu obszar potencjalnych zastosowań „,systemów otwartych" jest znacznie szerszy. ${ }^{17,18}$

Celem przeglądu piśmiennictwa było usystematyzowanie dostępnej wiedzy na temat wykorzystywanych materiałów, zakresu możliwości i techniki wykonywania uzupełnień tymczasowych w technologii cyfrowej.

Dokonano przeglądu piśmiennictwa wykorzystując bazę danych PubMed oraz Google Scholar używając kluczowych słów: „CAD/ CAM”, „PMMA”, „3D printers”. Do analizy zakwalifikowano w sumie 57 prac, spełniających założone kryteria. Po zawężeniu tematyki i dodaniu haseł „temporary restoration”, „temporary materials” wyodrębniono 40 prac, dotyczących nowoczesnych technologii cyfrowych.

Obecnie w stomatologii znajdują zastosowanie dwa systemy produkcji (CAM) zaprojektowanego uzupełnienia protetycznego: wykorzystujące metodę ubytkową - subtrakcyjną (frezowanie - CAD/CAM) lub metodę addytywną (druk 3D). ${ }^{8}$

\section{Technologia CAD/CAM}

Ze względu na wieloletnie wykorzystywanie urządzeń frezujących CAM, stanowią najczęściej stosowane systemy cyfrowe w protetyce stomatologicznej. W technice ubytkowej, nowoczesne pięcioosiowe frezarki CNC wytwarzają pełną gamę uzupełnień protetycznych z materiałów, takich jak: stop chromo-kobaltowy, tytan, tlenek cyrkonu oraz polimery najnowszej generacji. ${ }^{9}$ 
features that should be emphasized are: the remarkable quality and accuracy of the restoration obtained, time saving without the need to adjust the restoration in the occlusion and articulation, and the patient's full satisfaction. ${ }^{9,19}$ Thanks to $\mathrm{CAD} / \mathrm{CAM}$, it is possible not only to obtain an extremely tight- fitted temporary restoration, but also to eliminate the risk of material shrinkage and thermal damage to the pulp, which occurs when using traditional self-cured materials (acrylate and composite) directly in the patient's mouth. ${ }^{2}$ Currently, in CAD/CAM technology, the most frequently used material for making temporary restorations is methyl methacrylate resin - PMMA. PMMA is one of the oldest acrylate materials used in dentistry. It is available in the form of monochrome discs or multilayered resin for highly aesthetic restorations. The discs come in various thicknesses of 12, 16 and $20 \mathrm{~mm}$, and many shades according to the Vita 20 shade guide. The material is easy to mill and polish, has natural fluorescence, biocompatibility, resistance to plaque buildup and colour stability. Multilayered discs consist of 13 layers of different shades whose transition is undetectable to the human eye, making them a highly aesthetic material. ${ }^{17,21,22}$ The disadvantages of this technology include low fracture toughness, low elasticity modulus and the high cost of materials, devices and their maintenance. ${ }^{18,23-25}$ Contraindications to the use of PMMA are the patient's hypersensitivity to polymethyl methacrylate or any of the agents included in the product, extensive cantilever bridges and the use of a restoration as a permanent one. ${ }^{26}$ As a result of scanning, designing and then milling, a temporary restoration is ready to be cemented or intended for intraoral relining (shell). The obtained work can be mounted on a prepared abutment or a loaded implant, both in the anterior and posterior regions. ${ }^{27,28}$ The restoration can be cemented with traditional cements for temporary works or using the adhesive technique, and the durability in the
Dzięki technologii CAD/CAM istnieje możliwość wykonania indywidualnych uzupełnień tymczasowych, takich jak: pojedyncze korony, korony na implantach, mosty, mosty na implantach, try-in, uzupełnienia tymczasowe długoczasowe dla pacjentów młodocianych, uzupełnienia tymczasowe długoczasowe w przypadkach przebudowy zwarcia i wielospecjalistycznej rehabilitacji układu stomatognatycznego . Technologia ta umożliwia sprostać wymaganiom pacjentów pod względem estetycznym (dopasowanie do rysów i wielkości twarzy), a także funkcjonalnym. Dzięki tej technice, możliwe jest wykonanie odbudowy tymczasowej bezpośrednio w gabinecie stomatologicznym, przy pomocy urządzenia CEREC Sirona, a częściej pośrednio, przy udziale laboratorium techniki dentystycznej. ${ }^{16}$ Niezwykle ważną jej zaletą jest powtarzalność: technologia cyfrowa pozwala na zachowanie projektu w postaci zapisanego pliku, dzięki czemu kolejne wyfrezowanie tego samego uzupełnienia zajmuje jedynie kilka minut. Dodatkowo należy zaznaczyć jakość oraz dokładność uzyskanej odbudowy, a także oszczędność czasu bez konieczności dopasowywania uzupełnienia w okluzji statycznej i dynamicznej oraz pełną satysfakcję pacjenta. ${ }^{9,19}$

Dzięki technologii CAD/CAM można uzyskać nie tylko szczelne i dopasowane uzupełnienie tymczasowe, ale także wyeliminowane jest ryzyko skurczu materiału oraz termicznego uszkodzenia miazgi co może wystąpić w przypadku stosowania tradycyjnych materiałów chemoutwardzalnych (akrylanowych i kompozytowych) bezpośrednio w jamie ustnej pacjenta. ${ }^{2}$

Obecnie w technologii CAD/CAM najczęściej stosowanym materiałem do wykonywania uzupełnień tymczasowych jest PMMA- metylowa żywica metakrylanowa. PMMA należy do najstarszych materiałów akrylowych stosowanych w stomatologii. Dostępny jest w postaci dysków monochromatycznych lub multilayer - żywicy podzielonej warstwowo do 
oral cavity, according to the manufacturers, is expected to be up to two years. ${ }^{29,20}$

\section{$3 D$ printing}

In the digital 3D printing technique, restorations are created as a result of adding material, hardening the liquid or sintering the powder, as a result of which, layer by layer, a spatial prosthetic restoration is created. $8,30,31$ Among the additive methods, the following are used in dental prosthetics: FDM/FFF technology (fused deposition modelling/fused filament fabrication - modelling with a liquid thermoplastic), SLS (selective laser sintering), SLM (selective metal sintering), Jet Modelling, DLP (digital light processing - hardening the resin with UV light), SLA (stereolithography) and LFS (a type of stereolithography with a smaller laser spot). ${ }^{8,32}$ The most widely used techniques are SLA - stereolithography and DLP - resin curing with UV light, mainly for printing models, templates for dental implant, occlusive splints and prosthetic temporary restorations such as crowns, bridges, veneers or onlays. These systems consist of 3D printers that use UV light to polymerize the liquid 3D photopolymer resin layer by layer. ${ }^{33}$ These printers are no longer niche products, they are more and more accessible, smaller, lighter and faster than their prototypes. Unfortunately, little is known about the long-term properties of this technology. Compared to SLA, DLP is faster, more efficient, uses a wider range of light waves and enables the printing of small parts without wasting material. ${ }^{34,35}$ The printing speed depends on the size of the produced element, usually it is from several to several dozen minutes. The advantages include, above all, the possibility of precise printing of restorations with complex shapes, as in the case of the CAD/CAM system, the elimination of polymerization shrinkage and thermal damage to the pulp, as well as greater biocompatibility compared to traditional selfcured materials. ${ }^{35,36}$ The materials are available wysoko estetycznych odbudów. Krążki występują w różnych grubościach: $12,16,20 \mathrm{~mm}$ oraz wielu odcieniach według kolornika Vita. ${ }^{20}$ Materiał ten charakteryzuje się łatwością frezowania i polerowania, naturalną fluorescencją, biokompatybilnością, odpornością na odkładanie się płytki nazębnej oraz stabilnością koloru. Dyski multilayer składają się z 13 warstw o różnych odcieniach spójnie ze sobą połączonych, których zmiana jest niewykrywalna dla ludzkiego oka, dzięki czemu stanowią wysoce estetyczny materiał. ${ }^{17,21,22}$ Wadą tej technologii jest niska odporność na złamania, niski moduł elastyczności oraz wysoki koszt materiałów, urządzeń i ich konserwacji. ${ }^{18,23-25}$

Przeciwwskazaniami do stosowania PMMA są nadwrażliwość pacjenta na polimetakrylan metylu lub na którykolwiek z elementów wchodzących w skład danego produktu, rozległe mosty typu cantilever oraz zastosowanie uzupełnienia jako długoczasowe. ${ }^{26}$

Efektem skanowania, projektowania a następnie frezowania jest gotowe do zacementowania lub przeznaczone do podścielenia wewnątrzustnego (shell) uzupełnienie tymczasowe. Uzyskaną pracę można osadzić na oszlifowanym filarze lub obciążanym implancie, zarówno w odcinku przednim jak i bocznym. ${ }^{27,28}$

Uzupełnienie może być cementowane przy pomocy tradycyjnych cementów do prac tymczasowych lub z zastosowaniem techniki adhezyjnej, a trwałość w jamie ustnej, według producentów sięga nawet 2 lat. ${ }^{29,20}$

\section{Druk 3D}

W technice cyfrowej druku 3D, prace powstają w wyniku dodawania materiału, utwardzania cieczy lub spiekania proszku, w wyniku czego warstwa po warstwie powstaje przestrzenne uzupełnienie protetyczne. . $^{8} 30,31$

Wśród metod addytywnych, zastosowanie w protetyce stomatologicznej znalazły: technologia FDM/FFF (fused deposition modeling/ 
in many shades according to the Vita shade guide. ${ }^{33}$ In addition, Chaturvedi et al., based on their research from 2019, list an advantage of a more precise fit of printed restorations compared to milled and traditional ones. ${ }^{37}$ Unfortunately, the disadvantage is still the high costs and quick wear of the material during chewing, which is a significant factor in the case of long-term restorations during comprehensive rehabilitation of the stomatognathic system. Adding more filler, which increases the abrasion resistance of the material, may be a solution to the problem. ${ }^{35,38}$ It should be noted that despite reports on the increased abrasion of 3D resins, there are numerous studies demonstrating that their abrasion is comparable to the already commonly used other temporary materials. ${ }^{35} 3 \mathrm{D}$ resins are available in many shades, and it is also possible to characterize them individually. In addition, they show high polishability, dimensional stability and no taste or smell. ${ }^{39}$ According to the manufacturers, the material has been cleared for contact with human tissue for a period of twelve months. ${ }^{33}$ Temporary restorations can be cemented traditionally or with the use of an adhesive technique in the case of anterior and long-term restorations, which are part of a multispecialist treatment and rehabilitation plan.

\section{Conclusion}

Temporary restorations are an indispensable element of modern dental prosthetic treatment. New materials with various properties and applications are being launched on the dental market. D due to the growing awareness and requirements of patients, it is extremely important to improve the quality, durability and aesthetics of new products, including those for temporary restorations, and to introduce them into everyday prosthetic practice. ${ }^{40}$ fused filament fabrication- modelowanie ciekłym tworzywem termoplastycznym), SLS (selektywne spiekanie laserowe), SLM (selektywne spiekanie metali), JetModeling (modelowanie strumieniowe), DLP (digital light processing- utwardzanie żywicy światłem UV), SLA (stereolitografia) oraz LFS (odmiana stereolitografii o mniejszej plamce lasera). ${ }^{8,32}$

Do najszerzej stosowanych należą techniki SLA - stereolitografia i DLP - utwardzanie żywicy światłem UV, głównie w celu drukowania modeli, szablonów implantologicznych, szyn okluzyjnych oraz protetycznych uzupełnień tymczasowych, takich jak korony, mosty, licówki czy nakłady. W tych technologiach stosowane są drukarki 3D wykorzystujące światło UV, które polimeryzują płynną fotopolimerową żywicę 3D warstwa po warstwie. ${ }^{33}$ Drukarki te są coraz bardziej dostępne, mniejsze, lżejsze oraz szybsze w porównaniu ze swoimi prototypami. Wciąż jednak mało jest informacji o właściwościach tej technologii w długim okresie użytkowania. DLP w porównaniu z SLA jest systemem szybszym, bardziej wydajnym, wykorzystuje szerszy zakres fal światła oraz umożliwia drukowanie małych elementów. ${ }^{34,35}$ Szybkość druku zależy od wielkości produkowanego elementu, zazwyczaj wynosi on od kilku do kilkudziesięciu minut. Do zalet należy zaliczyć przede wszystkim możliwość precyzyjnego drukowania uzupełnień o skomplikowanych kształtach, podobnie jak w przypadku techniki CAD/CAM eliminację skurczu polimeryzacyjnego oraz termicznego uszkodzenia miazgi, a także większą biokompatybilność w stosunku do tradycyjnych materiałów chemoutwardzalnych. ${ }^{35,36}$ Materiały występują w wielu odcieniach według kolornika Vita. ${ }^{33}$ Dodatkowo Chaturvedi i wsp. na podstawie swoich badań z 2019 roku podają jako zaletę dokładniejsze dopasowanie uzupełnień drukowanych w porównaniu do frezowanych i wykonywanych tradycyjnie. ${ }^{37}$ Wadą są wciąż wysokie koszty oraz szybkie zużywanie się 
materiału w akcie żucia, co jest bardzo ważnym czynnikiem w przypadku długotrwale użytkowanych uzupełnień czasowych podczas kompleksowej rehabilitacji układu stomatognatycznego. Rozwiązaniem problemu wydaje się być dodawanie większej ilości wypełniacza, co zwiększa odporność materiału na ścieranie. ${ }^{35,38}$ Należy zaznaczyć, że mimo doniesień o zwiększonej ścieralności żywic 3D, pojawiają się liczne badania, przedstawiające w swoich wynikach porównywalną ich ścieralność do już powszechnie stosowanych innych materiałów tymczasowych. ${ }^{35}$

Żywice 3D dostępne są w wielu odcieniach, a także istnieje możliwość indywidualnej ich charakteryzacji. Dodatkowo wykazują wysoką polerowalność, stabilność wymiarów oraz brak smaku i zapachu. ${ }^{39}$ Według producentów, materiał został dopuszczony do kontaktu z ludzką tkanką na okres 12 miesięcy. ${ }^{33}$
Uzupełnienia tymczasowe można cementować tradycyjnie lub z zastosowaniem techniki adhezyjnej w przypadku prac w odcinku przednim oraz prac długoczasowych, będących elementem wielospecjalistycznego planu leczniczo-rehabilitacyjnego.

\section{Podsumowanie}

Uzupełnienia tymczasowe stanowią niezbędny element współczesnego leczenia protetycznego. Na rynku stomatologicznym stale pojawiają się nowe materiały o różnych właściwościach i zastosowaniach. W codziennej pracy, w związku z rosnącą świadomością oraz wymaganiami pacjentów, niezwykle ważna jest poprawa jakości, wytrzymałości oraz estetyki pojawiających się nowych produktów, także tych na uzupełnienia tymczasowe oraz wprowadzanie ich do codziennej praktyki protetycznej. ${ }^{40}$

\section{References / Piśmiennictwo}

1. Hayashi K, Maeno M, Nara Y: Influence of immediate dentin sealing and temporary restoration on the bonding of $\mathrm{CAD} / \mathrm{CAM}$ ceramic crown restoration. Dent Mater J 2019; 38(6): 970-980.

2. Czelej-Piszcz E, Piórkowska-Skrabucha B, Sarna-Boś K, Szabelska A, Borowicz J: Conductivity of heat produced during the polymerization of materials for temporary restorations by the dentin layer. Prosthodontics 2012; 62(2): 110-114.

3. Burns DR, Beck DA, Nelson SK: A review of selected dental literature on contemporary provisional fixed prosthodontic treatment. t:Report of the Committee on Reserch in Fixed Prosthodontics of the Academy of Fixed Prosthodontics. J Prosthet Dent 2003: 90, 5: 474-497.

4. Sari T, Usumez A, Strasser T, Şahinbas A, Rosentritt $M$ : Temporary materials: comparison of in vivo and in vitro performance.
Clin Oral Investig 2020; 24(11): 4061-4068.

5. Nold J, Wesemann C, Rieg L, Binder L, Witkowski S, Spies BC, Kohal RJ: Does Printing Orientation Matter? In-Vitro Fracture Strength of Temporary Fixed Dental Prostheses after a 1-Year Simulation in the Artificial Mouth. Materials (Basel) 2021; 14(2): 259.

6. Blatz MB, Conejo J. The Current State of Chairside Digital Dentistry and Materials. Dent Clin North Am 2019; 63(2): 175-197.

7. Białoskórska K, Szczyrek P. Intraoral scannersapplication opportunities in everyday practice. Prosthodontics 2019; 69(4): 419-426.

8. Wróbel-Bednarz K, Surowiecki D: Application and properties of $3 \mathrm{D}$ printing technology, the future of prosthodontics. Prosthodontics 2016; 66(6): 453-460.

9. Cywoniuk E, Sierpińska T. Wykorzystanie technologii cyfrowych w wykonawstwie uzupełnień protetycznych na podstawie piśmien- 
nictwa. Prosthodontics 2019; 69(2): 207-216.

10. Bębenek K, Błaszczyk A, Kiryk J, Kotowski D, Kowalska K, Szczygielski T, Mazgajczyk E, Szymczyk P, Badora G, Bryła E, Dobrzyński $M$, Rybak Z: Zastosowanie technologii CAD/ CAM w stomatologii odtwórczej : przegląd piśmiennictwa. Inżynier i Fizyk Medyczny 2016; 5(2): 99-104.

11. Ahmed KE: We're Going Digital: The Current State of CAD/CAM Dentistry in Prosthodontics. Prim Dent J Summer 2018; 7(2): 30-35.

12. Patzelt SBM, Lamprinos $C$, Stampf S, Att W: The time efficiency of intraoral scanners: an in vitro comparative study. J Am Dent Assoc 2014; 145(6): 542-551.

13. Fukazawa $S$, Odaira $C$, Kondo H: Investigation of accuracy and reproducibility of abutment position by intraoral scanners. J Prosthodont Res 2017; 61(4): 450-459.

14. Camardella LT, Breuning H, de Vasconcellos Vilella $O$ : Accuracy and reproducibility of measurements on plaster models and digital models created using an intraoral scanner. J Orofac Orthop 2017; 78(3): 211-220.

15. Lee SJ, Gallucci GO: Digital vs. conventional implant impressions: efficiency outcomes. Clin Oral Implants Res 2013; 24(1): 111-115.

16. Almeida e Silva JS, Erdelt K, Edelhoff D, Araújo É, Stimmelmayr M, Clovis Cardoso Vieira L, Güth JF: Marginal and internal fit of four-unit zirconia fixed dental prostheses based on digital and conventional impression techniques. Clin Oral Investig 2014; 18(2): 515-523.

17. Shenoy VK, Prabhu MB: Computer-aided design/computer-aided manufacturing in dentistry - Future is present. J Interdisciplinary Dent 2015; 5(2): 60.

18. Juszczyszyn K, Rolski D, MierzwińskaNastalskaE: The use ofCAD/CAM technology in prosthetic rehabilitation of patients treated for maxillary tumors. Prosthodontics 2019; 69(3): 313-321.

19. Kuźniar-Folwarczny A, Sulewski M, Błaszczyk
A, Sulewska A, Kosior P, Dobrzyński M: Characteristic of ceramic dental materials used with CAD/CAM chairside systems. Inżynier i Fizyk Medyczny 2019; 8: 479-487.

20. LuxaCam PMMA - Ronde Instrukcja użycia https://pl.dmg-dental.com/

21. Rogula J, Kuźniar-Folwarczny A, Sulewski M, Btaszczyk A, Sulewska A, Kosior P, Dobrzyński $M$ : Charakterystyka kompozytowych materiałów stomatologicznych stosowanych w gabinetowych systemach cad/cam. Inżynier i Fizyk Medyczny 2020; 9: 57-61.

22. https://pl.dmg-dental.com/pl/produkty/product/luxacam-pmma

23. Dejak B: Kompendium wykonywania uzupełnień protetycznych. Med Tour Press Inter 2014.

24. Geiisberger M: Stomatologia estetyczna w praktyce klinicznej. Elsevier. 2012.

25.Dursun E, Monnier-Da Costa A, Moussally $C$ : Chairside CAD/CAM Composite Onlays for the Restoration of Primary Molars. J Clin Pediatr Dent 2018; 42(5): 349-354.

26. Instrukcja postępowania:PMMA for brain ${ }^{\circledR}$.

27. Pietruski JK, Pietruska MD: Materiały i technologie używane we współczesnej protetyce stałych uzupełnień zębowych - wady i zalety przedstawione na podstawie przeglądu piśmiennictwa. Stomatol Estetyczna 2013; 9(3): 89-99.

28. Blaszczyszyn A, Gedrange T, Dominiak M: Natychmiastowe obciążenie implantu z cienko gwintowaną szyjką - resorpcja kości oraz rezultat kliniczny, uzupełnienia pojedynczego zęba w szczęce. PSI Implant Dentistry 2013; 2(8): 40-47.

29. Edelhoff D, Beuer F, Schweiger J, Brix O, Stimmelmayr $M$, Guth JF: CAD/CAMgenerated high-density polymer restorations for the pretreatment of complex cases: a case report. Quintessence Int 2012; 43(6): 457-467.

30. Nowicki A, Jagucka-Mętel W, Sobolewska $E$ : Drukarki 3d - możliwości zastosowania w praktyce stomatologicznej. Mag Stomatol 2015; 11: 74-76. 
31. Noort $R$ : The future of dental devices is digital. Dent Mater 2012; 28: 3-12.

32. https://cadxpert.pl/technologie-druku-3d/ technologia-sla/.

33. Drukowanie 3D tymczasowych koron i mostów na podstawie skanu 3D - poradnik użytkownika. https://cadxpert.pl/poradnik-tymczasowe-korony-i-mosty-z-drukarki-3d.

34. Kadry H, Wadnap S, Xu C, Ahsan F: Digital light processing (DLP) 3D-printing technology and photoreactive polymers in fabrication of modified-release tablets. Eur J Pharm Sci 2019; 135: 60-67.

35. Kessler A, Reymus M, Hickel R, Kunzelmann $K H$ : Three-body wear of 3D printed temporary materials. Dent Mater 2019; 35(12): 18051812.

36. Park JH, Lee H, Kim JW, Kim JH: Cytocompatibility of $3 \mathrm{D}$ printed dental materials for temporary restorations on fibroblasts. BMC Oral Health 2020; 20(1): 157.
37. Chaturvedi S, Alqahtani NM, Addas MK, Alfarsi MA: Marginal and internal fit of provisional crowns fabricated using 3D printing technology. Technol Health Care 2020; 28(6): 635-642.

38. Keßler A, Hickel R, Ilie $N$ : In vitro investigation of the influence of printing direction on the flexural strength, flexural modulus and fractographic analysis of 3D-printed temporary materials. Dent Mater J 2021.

39. FREEPRINT ${ }^{\circledR}$ temp https://www.detax.de/.

40. Kuźniar-Folwarczny A, Sulewski M, Błaszczyk A, Sulewska A, Kosior P, Dobrzyński M: Charakterystyka ceramicznych materiałów stomatologicznych stosowanych w gabinetowych systemach CAD/CAM. Inżynier i Fizyk Medyczny 2019; 8(6): 479-487.

Zaakceptowano do druku: 30.08.2021 r.

Adres autorów: 15-276 Białystok, ul. M. Skłodowskiej-Curie 24A.

C Zarząd Główny PTS 2021. 